\title{
Age related variability in the effects of mivacurium in paediatric surgical patients
}

Barbara W. Brandom MD, Olli A. Meretoja MD, * Eliahu Simhi MD, Tomi Taivainen MD, * Steven R. Wolfe BS, Susan K. Woelfel MD, Brian J. Gronert MD, D. Ryan Cook MD

Purpose: This study describes the effects of $0.3 \mathrm{mg}^{-\mathrm{kg}^{-1}}$ mivacurium in 180 paediatric patients between the ages of one month and 13 yr.

Methods: Alternate patients at each of two geographic sites received nitrous oxide-halothane or nitrous oxide-opioid anaesthesia. Neuromuscular blockade was monitored by electromyography (Datex NMT). Blood pressure and heart rate were recorded from an automated oscillometer. Tracheal intubation was performed $90 \mathrm{sec}$ after administration of mivacurium and conditions were judged by the Krieg scale.

Results: There was no difference in the time course of block between anaesthetics or geographic sites. The average time to $90 \%$ block and $25 \%$ recovery was $1.0 \mathrm{~min}$ and $8.0 \mathrm{~min}$ at one month $\mathrm{rs} 2.3 \mathrm{~min}$ and $9.8 \mathrm{~min}$ at $12.5 \mathrm{yr}$ of age. Intubation conditions were better during opioid (excellent in $92 \%$ ) than during halothane anaesthesia (excellent in 78\%) $(P=0.03)$. Diaphragmatic movement was less frequent in younger patients $(P<0.001)$. Intubation conditions did not differ between the two geographic sites. In the first minute after mivacurium, systolic and diastolic blood pressures decreased $(P<0.001)$ to similar extents in all patients. A transient increase in the redness of the skin of the face, trunk, and/or arms was noted during both anaesthetics ( $28 \%$ of infants, and $61 \%$ of children over five yr of age).

Conclusion: The time course of block produced by mivacurium is more rapid in younger paediatric patients. The time course of mivacurium does not have the transatlantic variation which has been observed for vecuronium. Physiological changes suggestive of histamine release were frequent. Intubation conditions were very likely to be acceptable $90 \mathrm{sec}$ after $0.3 \mathrm{mg} \cdot \mathrm{kg}^{-1}$ mivacurium.

Objectif : Cette étude décrit les effet de $0,3 \mathrm{mg} \cdot \mathrm{kg}^{-1}$ de mivacurium chez 180 patients pédiatriques agés de un mois à 13 ans.

Méthodes : Sur deux sites géographiques différents, les patients ont reçu de façon altemative une anesthésie halothane$\mathrm{N}_{2} \mathrm{O}$ ou opiacé- $\mathrm{N}_{2} \mathrm{O}$. Le bloc neuromusculaire a été surveillé par électromyographie (Datex NMT). La pression artérielle et la fréquence cardiaque ont été enregistrés par un appareil automatique fonctionnant par oscillométrie. Lintubation trachéale a été réalisée $90 \mathrm{sec}$ après l'administration de mivacurium et les conditions évaluées selon l'échelle de Krieg.

Résultats : II n'y avait pas de différence dans les caractéristiques temporelles du bloc selon l'anesthésie ou selon le site géographique. Le temps moyen pour obtenir $90 \%$ de bloc neuromusculaire d'une part et $25 \%$ de récupération d'autre part était de 1,0 min et de 8,0 min à l'âge de 1 mois vs 2,3 min et 9,8 min à 12,5 ans. Les conditions d'intubation étaient meilleures sous anesthésie avec opiacé (excellentes $=92 \%$ ) que sous anesthésie à l'halothane (excellentes $=78 \%$ ) $(P=0,03)$. Les mouvements diaphragmatiques étaient moins fréquents chez les patients plus jeunes $(P<0,001)$. Les conditions d'intubation étaient analogues sur les deux sites géographiques. Durant la première minute après le mivacurium, les pressions systolique et diastolique ont diminué $(P<0,001)$ de façon analogue chez tous les patients. Une rougeur transitoire de la peau de la figure, du tronc et/ou des bras a été notée durant les deux types d'anesthésies chez $28 \%$ des nourrissons et $61 \%$ des enfants de plus de 5 ans.

Conclusion : Linstallation du bloc produit par le mivacurium est plus rapide et la durée d'action plus courte chez les patients pédiatriques les plus jeunes. On ne retrouve pas pour le mivacurium les variations transatlantiques de temps, tant pour l'installation que pour la durée du bloc, retrouvées avec le rocuronium. Des changements physiologiques suggestifs de relâche d'histamine sont survenus fréquemment. Les conditions d'intubations avaient toutes les chances d'être acceptables 90 secondes après une dose de $0,3 \mathrm{mg} \cdot \mathrm{kg}^{-1}$ de mivacurium.

From the Departments of Anesthesiology, Children's Hospital of Pittsburgh and the University of Pittsburgh, Pittsburgh, Pennsylvania, USA, and Children's Hospital of Helsinki* and the University of Helsinki, Finland.

Financial support for this study was received from Glaxo Wellcome Inc.

Address correspondence to: Barbara W. Brandom MD, Department of Anesthesiology, Children's Hospital of Pittsburgh, 3705 Fifth Avenue, Pittsburgh, Pennsylvania 15213-2583 USA; Phone: 412-692-5260; Fax: 412-692-8658; E-mail: BWB+@pitt.edu

Accepted for publication January 24, 1998. 
$\mathrm{T}$

$\mathrm{HE}$ potency of mivacurium in paediatric patients has been described in terms of depression of evoked function of the adductor pollicis muscle after bolus and infusion. ${ }^{1-11}$ However, tracheal intubation conditions were documented in only four studies ${ }^{8-11}$ the largest of which ${ }^{9}$ included 25 children between one and $10 \mathrm{yr}$ of age in each experimental group. Due to its rapid metabolism by plasma cholinesterase ${ }^{12-14}$ the neuromuscular effects of mivacurium may be more variable than those of drugs with lower clearance. To describe adequately its variability in intubation conditions and neuromuscular block it may be necessary to observe larger numbers of patients. The question of age-related variability in response to a dose of mivacurium has not been addressed previously. Therefore, we evaluated the effects of mivacurium in 180 patients between one month and 13 yr of age. This study observed the time course of the neuromuscular effects of $0.3 \mathrm{mg} \cdot \mathrm{kg}^{-1}$ mivacurium, change in heart rate (HR) and blood pressure (BP), and ease of intubation $90 \mathrm{sec}$ after rapid injection during two anaesthetic conditions. Thus, there were 90 patients in each experimental group. Ninety seconds after injection of mivacurium was chosen as the best time for intubation on the basis of a previous study ${ }^{11}$ which found that intubation conditions before $90 \mathrm{sec}$ were not as likely to be excellent.

\section{Methods}

This was a descriptive, open-label, two centre study of paediatric patients during nitrous oxide-halothane or nitrous oxide-opioid anaesthesia. Written informed consent was obtained from a parent. The study was approved by the Human Rights Committees of the Children's Hospital of Pittsburgh and the Children's Hospital of the University of Helsinki.

One hundred and eighty infants and children (ASA I-II) between the ages of one month and $13 \mathrm{yr}$ were observed after $0.3 \mathrm{mg} \cdot \mathrm{kg}^{-1}$ mivacurium. Ninety patients completed the study at each site. A total of 193 patients were enlisted to accomplish this goal. Patients were enrolled into one of three groups based on age as they presented for surgery. Group 1 included patients less than one year of age, group 2 included patients one to less than five yr of age, and group 3 included patients five to less than $13 \mathrm{yr}$ of age. Alternate patients in each age group received either halothane or opioid based anaesthetics. There were 30 patients in each anaesthetic group in each age category. All patients were within $30 \%$ of ideal body weight. No patient had impairment of hepatic or renal function. None were exposed to bronchodilators, steroids, or antiepileptic drugs within the previous six months, or antihistamines, aminoglycosides, polypeptides, or tetracyclines within $48 \mathrm{hr}$ of the study. All infants six months of age or less received $0.2-0.3 \mathrm{mg} \cdot \mathrm{kg}^{-1}$ midazolam intranasally $5-20 \mathrm{~min}$ before induction of anaesthesia. Patients older than six months received either $0.2-0.3 \mathrm{mg} \cdot \mathrm{kg}^{-1}$ midazolam intranasally at $5-20 \mathrm{~min}$, or $0.5-0.7 \mathrm{mg} \cdot \mathrm{kg}^{-1} \mathrm{po}$ at 45-60 $\mathrm{min}$ before induction.

In patients receiving halothane, anaesthesia was induced with nitrous oxide $60-70 \%$, oxygen $30-40 \%$, and halothane up to $3 \%$ inspired. Halothane was reduced to $2 \%$ inspired when the patient had no eyelash reflex and no movement occurred in response to inflation of the blood pressure cuff, placement of skin electrodes, or application of a tourniquet. For two minutes, ventilation was assisted with nitrous oxide $60-70 \%$ in oxygen and halothane $2 \%$. During this time an intravenous (iv) catheter was inserted, baseline blood pressure (systolic (SBP), diastolic (DBP), mean (MAP)) and HR were recorded using a Dinamap (Critikon Inc., Tampa, Florida), and calibration of the neuromuscular transmission monitor (NMT) (Datex, Helsinki, Finland) was performed. The average age of the 90 children receiving halothane was 4.2 [range, 0.1-12.7] yr, the average weight was 17.6 [range, $4.2-42.0] \mathrm{kg}$. The time from the start of inhalation anaesthesia to the injection of mivacurium was $4.4 \pm 0.7$ (SD) min.

In patients receiving opioid anaesthesia an $i p$ catheter was placed during inhalation of nitrous oxide and oxygen and $2-4 \mu \mathrm{g} \cdot \mathrm{kg}^{-1}$ fentanyl were given incrementally. Two minutes after the initial dose of fentanyl, $5 \mathrm{mg} \cdot \mathrm{kg}^{-1}$ thiopentone was administered. During the time between the first dose of fentanyl and the bolus of thiopentone, the baseline BP and HR were recorded using a Dinamap, and calibration of the NMT was performed. The average age of the 90 children receiving opioid anaesthesia was 4.4 [range, $0.2-12.8$ ] $\mathrm{yr}$, the average weight was 17.6 [range, $4.0-48.0$ ] $\mathrm{kg}$. The time from the start of nitrous oxide and oxygen to the injection of mivacurium was $5.5 \pm 1.6(\mathrm{SD}) \mathrm{min}$.

A single supramaximal stimulus at $0.1 \mathrm{~Hz}$ was delivered to the ulnar nerve via surface electrodes proximal to the wrist. The evoked electromyogram (EMG) of the adductor pollicis was recorded with the NMT. ${ }^{15}$ Neuromuscular stimulation continued until the EMG response had recovered to at least $25 \%$ of the initial baseline EMG $\left(\mathrm{T}_{25}\right)$. The Dinamap and the $i v$ catheter were placed on the opposite arm from the NMT.

Two minutes after halothane was turned to $2 \%$ inspired or immediately following the injection of thiopentone, a bolus dose of $0.3 \mathrm{mg} \cdot \mathrm{kg}^{-1}$ mivacurium was administered over five seconds or less, and, if given, halothane was reduced to $1 \%$ inspired. The SBP, DBP, MAP, and HR were measured each minute for five minutes after injection of mivacurium. No other drugs 
other than fentanyl were given following mivacurium until $T_{25}$ was observed.

Ninety seconds after the completion of the injection of mivacurium, tracheal intubation was initiated by experienced full-time paediatric anaesthetists. Intubation conditions were graded on a scale of $1-4$ using Krieg's scale. ${ }^{16}$ (Table I). After administration of mivacurium and tracheal intubation, changes in skin colour of the face, trunk, and/or extremities or the skin near the injection site were noted. An increase in redness of the skin was described as a flush.

Neuromuscular blockade data underwent probit transformation to reduce heteroscedasticity. Following analysis the results were transformed back to percent block. The maximum block and block at the beginning and end of intubation, the time to $90 \%$ block $\left(\mathrm{B}_{90}\right)$, the time to maximum block, and time to $25 \%$ recovery $\left(\mathrm{T}_{25}\right)$ were compared across sites and anaesthetics by factorial analysis of covariance with age as a continuous variable. Recovery was referenced to the initial baseline. Changes in SBP, DBP, and HR were assessed with factorial repeated measures analysis of variance over five minutes with site and anaesthetic as factors and age as a continuous variable. Intubation scores were also compared across sites and anaesthetics with age as a continuous variable. Chi-square statistics evaluated the significance of nominal data such as the incidence of excellent intubations and flushing. Statistical analysis was performed in SAS 6.1 (SAS Institute Inc., SAS Circle, Box 8000, CARY, North Carolina, USA, 27512-8000).

Data are presented as the mean with standard deviation, median, and range. Statistical significance was defined as $P<0.05$.

If a patient was found to have slow recovery of neuromuscular function, i.e., $T_{25}>20 \mathrm{~min}$, plasma was obtained for measurement of plasma cholinesterase (BuChE) activity by a commercial laboratory (MetPath Laboratories, 875 Greentree Road, Pittsburgh, Pennsylvania 15220-3610) that used propionylthiocholine as substrate. Inhibition by dibucaine was also

TABLE I Intubation conditions

\begin{tabular}{|c|c|c|}
\hline Grade & Classification & Description \\
\hline 1 & excellent & $\begin{array}{l}\text { No movement of the diaphragm } \\
\text { Vocal cords relaxed }\end{array}$ \\
\hline 2 & good & $\begin{array}{l}\text { Weak movements of the diaphragm } \\
\text { Vocal cords relaxed or in the mid position }\end{array}$ \\
\hline 3 & poor & $\begin{array}{l}\text { Significant coughing requiring adjustment } \\
\text { of ventilation pressure } \\
\text { Vocal cords may be moderately adducted }\end{array}$ \\
\hline 4 & not possible & Vocal cords tightly adducted \\
\hline
\end{tabular}

As defined by Krieg $^{16}$ documented. If a patient had abnormal BuChE activity, neuromuscular data were not included in statistical analysis.

\section{Results}

A total of 193 patients were entered into the study, 180 provided data for analysis. Data from 13 patients were replaced due to protocol violations or technical problems. One patient, with $\mathrm{T}_{25}$ of $24 \mathrm{~min}$, was found postoperatively to have low plasma cholinesterase activity $\left(2.7 \mathrm{U} \cdot \mathrm{ml}^{-1}\right.$, normal range $=2.8-11.0 \mathrm{U} \cdot \mathrm{ml}^{-1}$; inhibition by dibucaine was $57.5 \%$, normal range $=77.0-83.0 \%$ ) typical of heterozygous dibucaine resistance. ${ }^{17}$

Analysis of covariance found no significant difference between the two geographic sites in the time course of block ( $P=0.30$ to 0.91$)$. Anaesthetic background had no relationship with $\mathrm{B}_{90}(P=0.48)$ or $\mathrm{T}_{25}(P=0.81)$. The median time to $B_{90}$ was 1.3 min with range of 0.3 to 5.0 $\mathrm{min}$, and the median time to maximum block was 2.2 $\mathrm{min}$, range of 0.3 to $6.5 \mathrm{~min}$. Maximum block ranged from $52 \%$ to $100 \%$. Median time to $T_{25}$ was $8.4 \mathrm{~min}$, range of 4.0 to $19.2 \mathrm{~min}$. Analysis of covariance demonstrated a relationship berween age and time to $\mathrm{B}_{90}(P=$ 0.0001). (Figure 1) Duration of block tended to be shorter in younger children. (Figure 2) All cases in which maximum block was observed less than two minutes after injection had $>95 \%$ block. Cases in which maximum block was observed more than two minutes after injection had effects ranging from $<75 \%-100 \%$ block. (Figure 3 ).

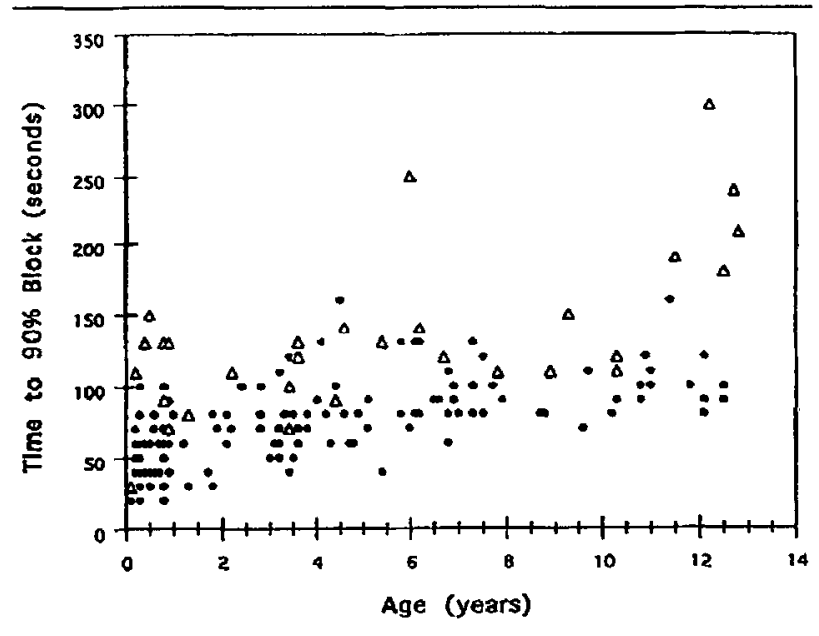

FIGURE 1 Age $p s$ time to $90 \%$ neuromuscular block. Seventeen patients were excluded from the plot due to a maximum block that was less than $90 \%$. - Patients in whom complete block of the adductor pollicis occurred. $\Delta$-Patients in whom maximum block was between $90 \%$ and $100 \% . B_{90}(\mathrm{sec})=57(\mathrm{sec})+6.06\left(\mathrm{sec} \cdot \mathrm{yr}^{-1}\right)$ $x$ age (yr) 
Intubation score was related to both age $(P<$ $0.001)$ and anaesthetic $(P=0.03)$, but not to geographic site $(P=0.89)$. There were 30 excellent intubations during opioid anaesthesia and 29 excellent intubations during halothane anaesthesia in infants $<$ one yr. There were 29 excellent intubations during opioid anaesthesia and 22 excellent intubations during halothane anaesthesia in children one to five yr. There were 25 excellent intubations during opioid anaesthesia and 19 excellent intubations during halothane anaesthesia in children five to $<13 \mathrm{yr}$. Other intubations conditions were judged to be good, except for one patient, $12 \mathrm{yr}$ of age, in whom tracheal intubation could not be performed $90 \mathrm{sec}$ after the injection of mivacurium during opioid anaesthesia. Neuromuscular block was $20 \%$ at the start of the intubation and the vocal cords were adducted in this patient. Without administration of additional intravenous drugs, his trachea was successfully intubated $90 \mathrm{sec}$ after the failure of the first attempt. Maximum neuromuscular block of $95.4 \%$ occurred $6.5 \mathrm{~min}$ after injection of mivacurium in this case.

The percent blockade at the start of intubation was related to age (i.e., more intense block was present in infants than in older children, $(P<0.005))$ but not to anaesthetic $(P=0.94)$ or geographic site $(P=0.95)$. Patients judged to have excellent intubation conditions had greater average block at the start of intubation, $97 \%$, than patients with good intubation conditions, $78 \%(P<0.005)$.

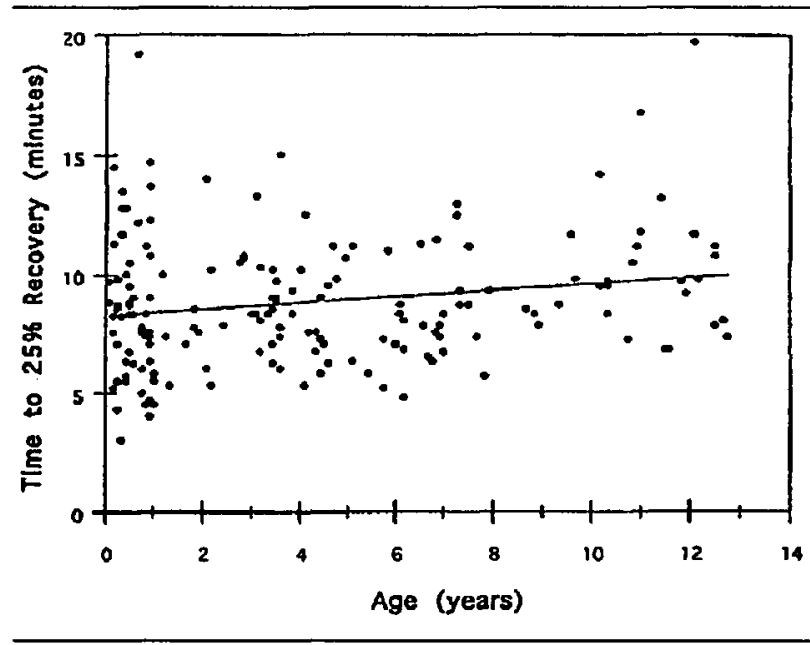

FIGURE 2 Age $p s$ time to $25 \%$ recovery $\left(\mathrm{T}_{25}\right)$. (The model predicting time to $T_{25}$ that included age, anaesthetic, and site was of marginal statistical significance. $)(P=0.06)$. Age was the most important part of this model $(P=0.01)$. Neither site $(P=0.59)$ nor anaesthetic $(P=0.81)$ were significant. $\mathrm{T}_{25}(\mathrm{~min})=7.94$ $(\min )+14.5\left(10^{-2}\right)\left(\mathrm{min} \cdot \mathrm{yr}^{-1}\right) \times$ age $(\mathrm{yr})$.
Repeated measures analysis of variance, with age, anaesthetic and geographic site as covariates, demonstrated a decrease in SBP $(P<0.001)$ between baseline and one minute after the injection of mivacurium, which was not related to age $(P=0.93)$, anaesthetic $(P=0.39)$, or geographic site $(P=0.59)$ (Table II). Similarly, the decrease in DBP $(P<0.001)$ between baseline and one minute was not related to age $(P=0.95)$ or site $(P=0.77)$, or anaesthetic $(P=0.11)$. Repeated measures analysis of variance demonstrated changes in $\mathrm{HR}$

TABLE II Cardiovascular data

\begin{tabular}{llllllll}
\hline & & \multicolumn{2}{c}{ SBP } & \multicolumn{2}{c}{ DBP } & \multicolumn{2}{c}{$H R$} \\
& Age group & Base & Min 1 & Base & Min 1 & Base & Min 1 \\
\hline Halothane & 1 & 86 & 76 & 49 & 40 & 126 & 125 \\
& 2 & 95 & 87 & 53 & 45 & 103 & 99 \\
& 3 & 96 & 92 & 54 & 48 & 88 & 96 \\
Opioid & 1 & 102 & 93 & 60 & 49 & 134 & 137 \\
& 2 & 103 & 99 & 61 & 53 & 113 & 119 \\
& 3 & 105 & 93 & 62 & 48 & 88 & 101 \\
\hline
\end{tabular}

Systolic blood pressure, diastolic blood pressure, and heart rate werc averaged for cach age group within each anacsthetic at baseline and $\min \mathrm{l}$ after the injection of mivacurium. Statistical significance is discussed in the text. There were $\mathbf{3 0}$ patients in cach age group within each anaesthetic background.

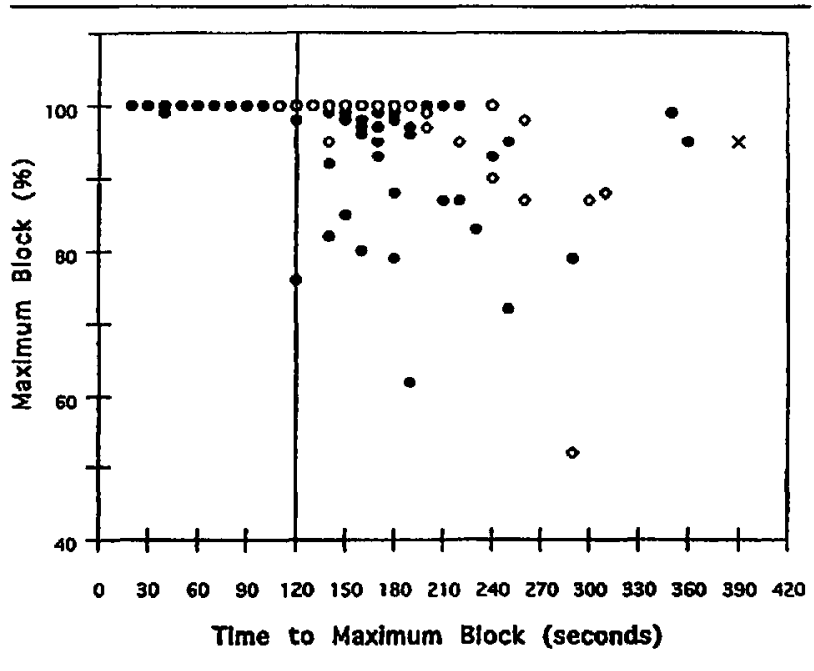

FIGURE 3 Time to maximum block (sec) vs the degree of block developed. When maximum block occurred $<120 \mathrm{sec}$ after the injection of mivacurium, intubations performed $90 \mathrm{sec}$ after injection of mivacurium were excellent $(\bullet)$ in 82 cases $(98 \%$ of total) and good $(\diamond)$ in two cases. When maximum block occurred $>120 \mathrm{sec}$ after mivacurium, the percentage of excellent intubations performed $90 \mathrm{sec}$ after the injection of mivacurium decreased to $74 \%$ of the total, or 70 cases. One intubation $90 \mathrm{sec}$ after injection of mivacurium was not possible $(\mathrm{X})$. 
$(P=0.02)$ from baseline to one minute that were related to age $(P<0.001)$ and anaesthetic $(P=0.01)$ but not to site $(P=0.59)$. Changes in $\mathrm{HR}$ at one minute were greater in patients receiving opioid anaesthetics and older patients receiving either anaesthetic. The change in SBP between baseline and one minute was not present four minutes after intubation. The DBP changes remained throughout the five minutes of observation, but DBP was lower than baseline only during the first two minutes after mivacurium injection and thereafter was greater than baseline. The HR continued to increase during the five minutes of observation. The increase in HR between baseline and one minute after the injection of mivacurium was lower than that during the four minutes following intubation. Graphic presentation of MAP and HR in all 180 patients (Figure 4) demonstrates the interpatient variability. Cardiovascular changes following administration of mivacurium did not require treatment.

Analysis of covariance demonstrated a difference in the incidence of flush with age $(P=0.0007)$ but no relationship with site $(P=0.06)$, or anaesthetic $(P=$ $0.94)$. There was a higher incidence of flush in the older patients during both halothane and opioid anaesthesia. Flushing was observed in $61 \%$ of children over five yr of age, in $30 \%$ of children one to five yr of

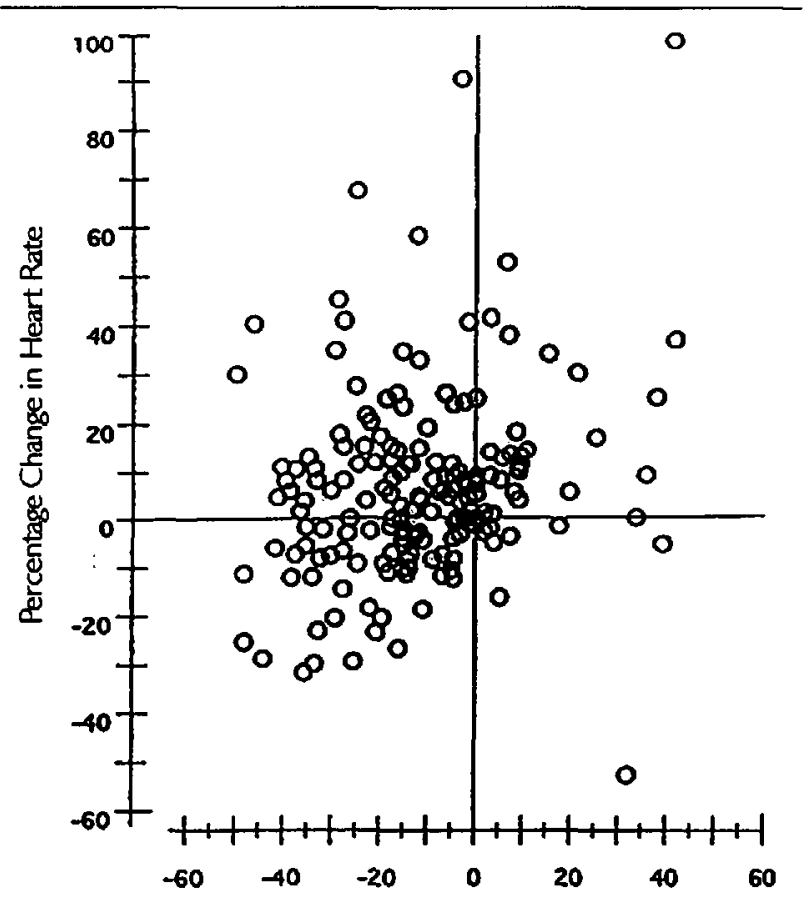

Percentage Change in Mean Arterial Blood Pressure

FIGURE 4 Percentage change in heart rate versus mean arterial blood pressure at one minute after administration of $0.3 \mathrm{mg} \cdot \mathrm{kg}^{-1}$ mivacurium. age, and in $28 \%$ of infants less than one year of age. There were 41 observations of flush in Pittsburgh and 31 in Helsinki, $P=0.06$. In addition, a total of 10 reactions consisting of transient redness at the injection site were noted.

\section{Discussion}

Patients were entered into one of three age groups in this study because the goal was to describe the effects of 0.3 $\mathrm{mg} \cdot \mathrm{kg}^{-1}$ mivacurium in infants, children, and preadolescents. Because age varies continuously, analysis of covariance with age as a covariate was a more powerful test than analysis of variance with age divided into three categories. Therefore, the analyses presented here were performed with age as a continuous variable. Nevertheless, the trend toward faster recovery from block in younger patients did not reach statistical significance. It is not surprising that there was a faster onset of block, and greater block at the time of intubation, in younger patients in this study, because mivacurium is slightly more potent in infants than in older children. Mivacurium, $0.3 \mathrm{mg} \cdot \mathrm{kg}^{-1}$, is about three times the $\mathrm{ED}_{95}$ in a child ${ }^{1,2}$ and four times the $\mathrm{ED}_{95}$ in an infant during halothane anaesthesia. ${ }^{5}$

It is interesting that there was no difference in the time course of neuromuscular block after mivacurium between patients in Pittsburgh and Helsinki (Finland), because transatlantic differences in time course of block $^{18,19}$ and in potency ${ }^{20}$ have been noted for some other neuromuscular blockers. It was suggested that the $30-40 \%$ transatlantic difference in potency and duration of action of vecuronium was most likely due to differences in protein binding or sensitivity of the neuromuscular junction. ${ }^{19}$ The lack of difference in time course of mivacurium suggests that there were no details of monitoring, anaesthetic administration or epidemiological factors affecting plasma cholinesterase activity which differed between Pittsburgh and Helsinki.

It may seem strange that there was no difference in the time course of block between patients who received halothane and those who did not. It has been shown that halothane potentiates block induced by mivacurium during infusion, but only when each patient serves as their own control., ${ }^{3,21}$ Thus, normal individual variability in plasma cholinesterase activity appears to be the predominant factor in determining both effective infusion rate and rate of recovery from mivacurium. In this study exposure to halothane before administration of mivacurium was deliberately kept as brief as possible so that the results would be clinically relevant. Because the latest time point measured in this study was $<25 \mathrm{~min}$ after initiation of halothane, and most of the measurements were obtained within $15 \mathrm{~min}$ of anaesthetic induction, it is not surprising that the potentiating 
effect of halothane on neuromuscular block ${ }^{21}$ was not demonstrated. The potentiating effect of halothane may reach a maximum of $30 \%$, but maximal effect may not be observed until at least 20 and often $60 \mathrm{~min}$ after halothane administration is begun. ${ }^{21}$

All patients in whom maximal block occurred less than two minutes after mivacurium was given had complete block $(100 \%)$, whereas many patients in whom maximal block occurred later than two minutes had much less block, consistent with the rapid clearance of mivacurium. ${ }^{12-14} \mathrm{~A}$ drug with a rapidly decreasing plasma concentration after administration of a bolus will have a variable peak effect due to variability in the rate of equilibration of drug in the blood with the effect site. Similar variability in effect may be seen after administration of succinylcholine. ${ }^{9}$ This suggests that starting an infusion of mivacurium at the same time that a bolus is administered would result in complete block in more patients. An infusion of mivacurium would replace the drug that was being metabolised before equilibration with the effect site occurred.

The anatomy of the patient, the skill of the endoscopist, the type of equipment used, the type and amount of anaesthetic administered, and the effects of the neuromuscular blocker can all influence the anaesthetist's judgement of intubation conditions. In this study, we chose to limit the effect of these variables by enlisting only patients who had normal airway anatomy, other than moderately enlarged tonsils; by documenting the skill level of the endoscopist; and by requiring strict adherence to a protocol of anaesthetic drugs in terms of both dose and timing. Thus, the results of this study may not apply to patients with abnormal anatomy, to anaesthetists who do not intubate the trachea of paediatric patients as routine practice, or to different anaesthetic conditions. Given these caveats this study demonstrates that good or excellent conditions for tracheal intubation are likely to be encountered $90 \mathrm{sec}$ after administration of $0.3 \mathrm{mg} \cdot \mathrm{kg}^{-1}$ mivacurium to anaesthetised paediatric patients. A previous study in children during thiopentone nitrous oxide anaesthesia found better intubation conditions at $90 \mathrm{sec}$ than at $60 \mathrm{sec}$ after administration of 0.2 $\mathrm{mg} \cdot \mathrm{kg}^{-1}$ of mivacurium. ${ }^{9}$ Similarly, during halothane anaesthesia in children, intubating conditions were better $90 \mathrm{sec}$ or later after administration of $0.3 \mathrm{mg} \cdot \mathrm{kg}^{-1} \mathrm{mivac}-$ urium than they were at earlier times. ${ }^{11}$ In a study which compared $0.2,0.3$, and $0.4 \mathrm{mg} \cdot \mathrm{kg}^{-1}$ mivacurium, intubation was performed when block of the adductor pollicis was noted but a formal comparison of intubation conditions was not reported. ${ }^{10}$ This was also the case in the study ${ }^{8}$ which compared intubation conditions after mivacurium with those after succinylcholine in infants and children. Together, these several studies suggest that tracheal intubation begun $90 \mathrm{sec}$ after administration of 0.2 or $0.3 \mathrm{mg} \cdot \mathrm{kg}^{-1}$ of mivacurium is likely to be associated with at most little movement of the diaphragm or vocal cords. However, the present study demonstrates that good intubating conditions are not guaranteed by a dose of $0.3 \mathrm{mg} \cdot \mathrm{kg}^{-1}$ with delay to $90 \mathrm{sec}$. The findings in these 180 cases suggest that monitoring of block at the adductor pollicis may help to predict excellent intubation conditions, in that when there was block of neuromuscular function at the thumb $90 \mathrm{sec}$ after administration of mivacurium, intubation conditions were excellent.

The better intubating conditions found in opioid than during halothane anaesthesia in the present study are not easy to explain. It may be that fentanyl and thiopentone more adequately suppressed movement of the diaphragm on stimulation of the trachea than $1 \%$ inspired halothane. However, thiopentone and nitrous oxide without a neuromuscular blocker have been shown to produce poor or impossible intubation conditions in children..$^{9}$ No other studies have compared intubation conditions following mivacurium administration during different types of anaesthesia in paediatric patients.

Multivariate analysis of changes in $\mathrm{HR}$ and $\mathrm{BP}$ after mivacurium and tracheal intubation examined the effects of anaesthetic and age on these variables. Although pressures were lower in the presence of halothane, decreases following administration of mivacurium were observed during both types of anaesthesia in patients of all ages. The decrease in BP and occurrence of flushing after rapid administration of mivacurium (over five sec or less) could be attributable to histamine. ${ }^{10}$ In a previous study, when this dose was administered over $15 \mathrm{sec},{ }^{10}$ the changes in BP observed were not significant. In the present study, it is most likely that the stimulus of tracheal intubation reversed the decrease in SBP which followed mivacurium and produced a greater tachycardia in older patients and those who were not exposed to halothane.

In conclusion, we have demonstrated that $0.3 \mathrm{mg} \cdot \mathrm{kg}^{-1}$ mivacurium could be used to facilitate tracheal intubation during different anaesthetic conditions in children of various ages. The onset of action of $0.3 \mathrm{mg} \cdot \mathrm{kg}^{-1}$ mivacurium was more rapid in infants than in older patients. However, there were frequent physiological changes suggestive of histamine release which may limit the use of this dose or larger doses administered over five seconds.

\section{Acknowledgments}

The authors thank David Wagner CRNA, Katherine Pyros CRNA, Susan Kelly CRNA, and Leena Räihä CRNA, for their time and dedication to this study and Heidi Richards for her significant assistance with statistical analysis. 


\section{References}

1 Sarner JB, Brandom BW, Woelfel SK, et al. Clinical pharmacology of mivacurium chloride (BW B1090U) in children during nitrous oxide-halothane and nitrous oxide-narcotic anesthesia. Anesth Analg 1989; 68: 116-21.

2 Goudsouzian NG, Alifimoff JK, Eberly C, et al. Neuromuscular and cardiovascular effects of mivacurium in children. Anesthesiology 1989; 70: 237-42.

3 Brandom BW, Sarner JB, Woelfel SK, et al. Mivacurium infusion requirements in pediatric surgical patients during nitrous oxide-halothane and during nitrous oxidenarcotic anesthesia. Anesth Analg 1990; 71: 16-22.

4 Alifimoff JK, Goudsouzian NG. Continuous infusion of mivacurium in children. Br J Anaesth 1989; 63: 520-4.

5 Woelfel SK, Brandom BW, McGowan FX Jr, Cook DR. Clinical pharmacology of mivacurium in pediatric patients less than two years old during nitrous oxidehalothane anesthesia. Anesth Analg 1993; 77: 713-20.

6 Meretoja OA, Olkkola KT. Pharmacodynamics of mivacurium in children, using a computer-controlled infusion. Br J Anaesth 1993; 71: 232-7.

7 Meretoja OA, Taivainen T, Wirtavuori K. Pharmacodynamics of mivacurium in infants. Br J Anaesth 1994; 73: 490-3.

8 Cook DR, Gronert BJ, Woelfel SK. Comparison of the neuromuscular effects of mivacurium and suxamethonium in infants and children. Acta Anaesthesiol Scand 1995; 39(Suppl 106): 35-40.

9 McCluskey A, Meakin G. Dose-response and minimum time to satisfactory intubation conditions after mivacurium in children. Anaesthesia 1996; 51: 438-41.

10 Shorten GD, Crawford MW, St. Louis P. The neuromuscular effects of mivacurium chloride during propofol anesthesia in children. Anesth Analg 1996; 82: 1170-5.

11 Simbi E, Brandom BW, Lloyd ME, Gronert BJ, Woelfel $S K$. Intubation in children after $0.3 \mathrm{mg} / \mathrm{kg}$ of mivacurium. J Clin Anesth 1997; 9: 576-81.

12 Cook DR, Freeman JA, Lai AA, et al. Pharmacokinetics of mivacurium in normal patients and in those with hepatic or renal failure. Br J Anaesth 1992; 69: 580-5.

13 Head-Rapson AG, Devlin JC, Parker CJR, Hunter JM. Pharmacokinetics of the three isomers of mivacurium and pharmacodynamics of the chiral mixture in hepatic cirrhosis. Br J Anaesth 1994; 73: 613-8.

14 Lien CA, Scbmith VD, Embree PB. Belmont MR, Wargin WA, Savarese JJ. The pharmacokinetics and pharmacodynamics of the stereoisomers of mivacurium in patients receiving nitrous oxide/opioid/barbiturate anesthesia. Anesthesiology 1994; 80: 1296-302.

15 Kalli I. Effect of surface electrode positioning on the compound action potential evoked by ulnar nerve stimulation in anaesthetized infants and children. Br J Anaesth 1989; 62: 188-93.
16 Krieg N, Mazur L, Booij LHDJ, Crul JF. Intubation conditions and reversibility of a new non-depolarizing neuromuscular blocking agent, Org-NC45. Acta Anaesthiol Scand 1980; 24: 423-5.

17 Whittaker M. Cholinesterase. In: Beckman L (Ed.). Monographs in Human Genetics, Vol 11. Basel, Switzerland: S. Karger AG, 1986: 93.

18 Katz RL, Norman J, Seed RF, Conrad L. A comparison of the effects of suxamethonium and tubocurarine in patients in London and New York. Br J Anaesth 1969; 41: 1041-7.

19 Salib Y, Frossard J, Plaud B, Debaene B, Meistelman C, Donati $F$. Neuromuscular effects of vecuronium and neostigmine in Montreal and Paris. Can J Anaesth 1994; 41: 908-12.

20 Fiset P, Donati F, Balendran P, Meistelman C, Lira E, Bevan DR. Vecuronium is more potent in Montreal than in Paris. Can J Anaesth 1991; 38: 717-21.

21 Meretoja OA, Wirtavuori K. Taivainen T, Olkkola KT. Time course of potentiation of mivacurium by halothane and isoflurane in children. $\mathrm{Br} J$ Anaesth 1996; 76: 235-8. 